\title{
BAPTISAN ROH KUDUS BERDASARKAN PERJANJIAN BARU
}

\author{
Jermia Djadi \\ jermiadjadi@ymail.com \\ sttjaffraymakassar@yahoo.co.id
}

\begin{abstract}
ABSTRAK
Karya ilmiah ini ditulis dengan membahas hal-hal berikut: analisis kata tentang baptisan Roh Kudus terhadap tujuh ayat dalam Perjanjian Baru yang berkaitan langsung dengan baptisan Roh Kudus, yaitu Matius 3:11; Markus 1:8; Lukas 3:16; Yohanes 1:33; Kisah 1:5; 11:26; dan 1 Korintus 12:13, yang menjelaskan bahwa baptisan dalam Roh Kudus ke dalam tubuh Kristus adalah untuk semua orang, yang meliputi semua orang yang telah percaya kepada Yesus, baik orang Yahudi maupun orang Yunani, baik budak maupun orang merdeka.

Baptisan dalam Roh Kudus dalam Perjanjian Baru yang meliputi: 1) Baptisan Roh Kudus bukan suatu pengalaman yang harus dicari dan diusahakan dan bukan pula merupakan berkat kedua sesudah pertobatan. Baptisan Roh Kudus pada hari Pentakosta adalah peristiwa bersejarah yang tak pernah diulang, satu kali untuk selama-lamanya, dengan mengikutsertakan semua orang percaya, yang terjadi pada saat orang percaya dan menerima Yesus Kristus sebagai Tuhan dan Juruselamat; 2) Baptisan Roh Kudus berlaku bagi orang-orang Samaria yang merupakan musuh turun-temurun bangsa Yahudi. Karena faktor historis, peristiwa itu harus disahkan oleh dua orang rasul Yahudi melalui penumpangan tangan. Kemudian mereka pun diterima dan dipersatukan dengan orang-orang percaya dari bangsa Yahudi menjadi satu tubuh Kristus tanpa mengenal perbedaan; 3) Baptisan dalam Roh Kudus juga berlaku bagi orang-orang bukan Yahudi (kafir) yang dipandang hina dan najis oleh bangsa Yahudi; 4) Baptisan Roh Kudus tidak berlaku bagi orang-orang yang belum menjadi Kristen, tetapi hanya untuk mereka yang percaya sungguh-sungguh kepada Kristus, seperti kelompok kedua belas murid Yohanes Pembaptis di Efesus.
\end{abstract}

Kata Kunci: Baptisan Roh Kudus, Perjanjian Baru 


\section{PENDAHULUAN}

Ada beberapa alasan yang mendasari penulisan ini karena adanya berbagai pandangan atau ajaran tentang baptisan Roh Kudus, antara lain:

Pertama, adanya pandangan-pandangan yang keliru tentang baptisan Roh Kudus, sehingga mengakibatkan kini ada dua golongan Kristen, yaitu: 1) Orang-orang Kristen golongan terbesar yang dianggap tidak memiliki baptisan Roh Kudus, mereka hanya bertobat dan belum mengalami pengudusan; 2) Semacam golongan Kristen elite yang menganggap diri telah memiliki baptisan Roh Kudus. Mereka adalah orang Kristen yang hidupnya telah disucikan. ${ }^{1}$

Kedua, timbulnya perbedaan-perbedaan pendapat tentang baptisan Roh Kudus, sehingga mengakibatkan terjadinya perpecahan dalam gereja Tuhan. Seharusnya perbedaan-perbedaan pendapat ini tidak sampai memecah belah gereja. ${ }^{2}$

Ketiga, meluasnya pengajaran yang mengatakan bahwa orang Kristen yang sudah diselamatkan belum menerima baptisan Roh Kudus, sehingga mengakibatkan banyak anak Tuhan mengalami kekusutan. Kesalahan tersebut meningkat pada pencampuradukan antara istilah baptisan Roh Kudus dan kepenuhan Roh Kudus. ${ }^{3}$

Keempat, munculnya ajaran bahwa baptisan Roh Kudus adalah suatu pengalaman yang terjadi sesudah pertobatan atau keselamatan. Secara umum ajaran ini memegang konsep bahwa walaupun Roh Kudus memperbarui seseorang dan membuatnya bertobat dan percaya kepada Kristus, namun Roh Kudus belum masuk ke dalam hati orang percaya itu dan memenuhi hidupnya secara sempurna sampai saat orang itu menerima baptisan Roh Kudus. ${ }^{4}$ Itulah sebabnya, ajaran mengenai baptisan Roh Kudus sebagai berkat kedua memainkan peranan yang semakin penting saat ini.

Kelima, Pengajaran tentang baptisan Roh Kudus merupakan salah satu isu teologi yang sangat menarik yang perlu dikembangkan.

\footnotetext{
${ }^{\mathrm{l}}$ Rudy Budiman, dalam L. Sugiri, Gerakan Kharismatik. Apakah Itu? (Jakarta: BPK Gunung Mulia, 1985), 171.

${ }^{2}$ Billy Graham, Roh Kudus (Bandung: Lembaga Literatur Baptis, 1978), 92.

${ }^{3}$ Tjhung Tek Kie, Parakletos (Surabaya: The Chinese Foreign Missionary Union Book Room, n.d.), 61.

${ }^{4} \mathrm{P}$. Ade Kolinus TB, Baptisan Roh Kudus Menurut Ajaran Kharismatik: Sebuah Tinjauan Alkitabiah, Cetakan Pertama (Bandung: Yayasan Kalam Hidup, 2000), 30.
} 


\section{ANALISIS KATA TENTANG BAPTISAN ROH KUDUS}

Ungkapan "baptisan Roh Kudus" terdapat dalam tujuh referensi ayat-ayat Perjanjian Baru. Dari ketujuh ayat tersebut, empat di antaranya terdapat dalam keempat Injil (Matius 3:1l; Markus 1:8; Lukas 3:16; Yohanes 1:33), dua ayat dalam Kisah Para Rasul (Kisah 1:5; 11:26) yang merupakan nubuat yang menunjuk pada waktu yang akan datang di mana nubuat tersebut telah dipenuhi atau digenapi pada hari Pentakosta (Kisah Para Rasul 2), dan satu-satunya ayat yang dalamnya baptisan Roh Kudus dipandang sebagai doktrinal, yaitu 1 Korintus 12:13.

Ungkapan "baptisan Roh Kudus" itu, selalu diterjemahkan oleh Lembaga Alkitab Indonesia, "baptisan dengan Roh Kudus." Kata en dalam bahasa Yunani dapat juga diterjemahkan "dalam", sehingga ungkapan itu menjadi "baptisan dalam Roh Kudus." Sehubungan dengan kata en, Carr menulis sebagai berikut, "Kata dengan en dalam bahasa Yunani digunakan untuk menyatakan instrumen (alat), tetapi kata depan itu dapat juga menyatakan elemen (unsur) di mana satu kegiatan itu terjadi." ${ }^{5}$

Ungkapan "baptisan dengan Roh Kudus" yang terdapat dalam keempat Injil dan yang kelima kalinya dalam Kisah 1:5, semuanya berhubungan dengan "baptisan dalam Roh Kudus," untuk membedakannya dari "baptisan dalam air". Dalam bahasa Yunani, kata en hudati atau en pneumati (bentuk datif), sama sekali tidak boleh diterjemahkan "oleh air" atau "oleh Roh", seolah-olah air dan Roh yang menjadi pelaku baptisan. Pelaku baptisan dalam ayat tersebut ialah Yohanes Pembaptis yang membaptis dalam air dan Yesus Kristus yang membaptis dalam Roh. Jadi, bukan air atau Roh sebagai pembaptis. Oleh karena itu, ungkapan en hudati atau en pneumati harus diterjemahkan "dalam air" atau "dalam Roh". Sebaliknya di dalam kitab Injil, janji tentang baptisan Roh Kudus itu diberikan untuk menunjukkan waktu yang akan datang, dalam bahasa Yunaninya baptisei (Matius 3:1l; Markus 1:8; Lukas 3:16). Dalam Injil Yohanes 1:33, unsur waktu yang menunjukkan waktu yang akan datang tidak ditemukan. Ayat itu berbunyi, “..., tetapi Dia yang (telah) mengutus aku untuk membaptis (baptizein, bentuk presen infinitif) dalam air, telah befirman kepadaku, Jikalau engkau melihat Roh itu turun ke atas seseorang dan tinggal di atas-Nya, Dialah itu yang akan membaptis (ho baptizon, present participle, the baptizing one) dengan Roh Kudus." Bentuk participle di sini, ho baptizon, menunjukkan orang yang akan membaptis dan bukan banyaknya

${ }^{5}$ Carr, dalam J. Oswald Sander, The Holy Spirit and His Gift (Grand Rapids, Michigan: Zondervan Publishing House, 1970), 63. 
tindakan yang dilakukan. Oleh karena itu, tidak perlu menempatkan kata itu dalam bentuk waktu yang akan datang. Dalam Kisah 1:5, ungkapan, "Kamu akan membaptis dengan Roh Kudus", dalam bahasa Yunani adalah baptisthesesthe, yaitu bentuk passive future, yang berarti bahwa tindakan ini akan terjadi pada waktu tertentu di waktu yang akan datang, satu kali untuk selama-lamanya. Unsur yang ditambahkan dalam Kisah 1:5 yang tidak terdapat dalam kitab Injil adalah keterangan waktu, kapan hal itu akan terjadi, "tidak lama lagi". Bilamanakah hal itu terwujud? Jawabnya ialah pada hari Pentakosta (Kisah 2). ${ }^{6}$

Ayat 1 Korintus 12:13 adalah merupakan yang ketujuh dan terakhir bahwa baptisan dalam Roh disebutkan secara khusus. Telah dijelaskan di atas bahwa ayat-ayat dalam Injil Matius 3:1l; Markus 1:8; Lukas 3:16; Yohanes 1:33 dan Kisah 1:5, semuanya berhubungan dengan nubuatan tentang baptisan dalam Roh Kudus sebagai suatu peristiwa bersejarah di waktu yang akan datang. Peristiwa yang keenam dalam Kisah 11:16, berhubungan dengan baptisan dalam Roh sebagai janji yang telah dipenuhi. Dalam 1 Korintus 12:13, kata kerja ebaptisthemen adalah kata kerja dalam bentuk aorist passive, yang berarti bahwa pada waktu yang lampau kita telah dibaptis. Lebih-lebih bentuk kata kerja aorist itu harus dipandang sebagai suatu pernyataan, bukan hanya bagi peristiwa Pentakosta, melainkan juga kepada berkatnya yang diterima secara pribadi oleh semua orang Kristen pada waktu pertobatannya di waktu yang lampau. ${ }^{7}$

Unsur baptisan adalah Roh Kudus. Unsur itu dinyatakan oleh kata depan en, "dalam" atau "dengan" satu Roh. Unsur itu dinyatakan oleh kata depan en, "dalam" atau "dengan" satu Roh. Oleh sebab itu, kata en heni pneumati (bentuk datif) harus diterjemahkan "dalam atau dengan satu Roh" dan sama sekali tidak boleh diterjemahkan "oleh satu Roh". Sebab tidak logis jika dalam ayat ini Roh Kudus bertindak sebagai pembaptis, sedangkan dalam keenam ayat lainnya mengenai baptisan Roh Kudus, yang bertindak sebagai pelaku baptisan adalah Yesus Kristus. Andaikata dalam 1 Korintus 12:13 ini, Roh Kudus menjadi pembaptis, apakah unsur baptisan yang di dalamnya orang dibaptis? Itu berarti tidak ada unsur baptisan, itu bukan baptisan yang sesungguhnya. Oleh sebab itu, unsur baptisan dalam ayat ini haruslah Roh Kudus. Walaupun tidak disebutkan dalam ayat ini, jelaslah bahwa pembaptis tidak lain Yesus Kristus sendiri karena ini cocok dengan keenam ayat lain mengenai baptisan dalam Roh Kudus.

\footnotetext{
${ }^{6}$ Spiros Zodhiates, The Hebrew-Greek Key Study Bible (Grand Rapid, Michigan: Baker Book House, 1985), 1317.

7John R.W. Stott, Baptisan dan Kepenuhan (Jakarta: BPK Gunung Mulia, n.d.), 27).
} 
Baptisan dalam satu Roh ke dalam tubuh Kristus adalah untuk semua orang (bahasa Yunani, pantes), yang meliputi semua orang yang telah percaya kepada Yesus, baik orang Yahudi maupun orang Yunani, baik budak maupun orang merdeka. Baptisan dalam Roh Kudus adalah suatu peristiwa bersejarah yang dilakukan oleh Yesus Kristus satu kali untuk selama-lamanya dengan mengikutsertakan semua orang percaya, yang terjadi pada saat orang percaya, ke dalam tubuh Kristus, yaitu gereja.

\section{SEJARAH BAPTISAN ROH KUDUS DALAM KISAH PARA RASUL}

Kisah Para Rasul sering disebut "kisah perbuatan Roh Kudus", khususnya yang berhubungan dengan baptisan dalam Roh Kudus, dipenuhi Roh Kudus, dan dipimpin Roh Kudus. ${ }^{8}$ Kalau diteliti lebih jauh, dapat pula dikatakan bahwa Kisah Para Rasul merupakan sejarah tentang baptisan Roh Kudus dalam pembentukan dan pengembangan gereja-Nya, di mana peristiwa bersejarah itu telah terjadi pada hari Pentakosta, ketika Roh Kudus turun ke atas semua orang Yahudi yang percaya, yang sedang berkumpul di Yerusalem, satu kali untuk selamalamanya. Walaupun ungkapan "baptisan Roh Kudus" tidak ditemukan dalam Kisah Para Rasul 2, tetapi peristiwa "pencurahan Roh Kudus" (Kisah 2:18,33) atau "pemberian karunia Roh Kudus" (Kisah 3:38) identik dengan baptisan dalam Roh Kudus yang terjadi di rumah Kornelius seperti yang dinyatakan oleh Petrus sebagai berikut, "Dan ketika aku mulai berbicara, turunlah Roh Kudus ke atas mereka, sama seperti dahulu ke atas kita. Maka teringatlah aku akan perkataan Tuhan: Yohanes membaptis dengan air, tetapi kamu akan dibaptis dengan Roh Kudus" (Kisah 1l:15-16). Berdasarkan pernyataan itu, untuk uraian selanjutnya penulis akan menggunakan ungkapan "baptisan Roh Kudus" atau "baptisan dalam Roh Kudus" secara konsisten dalam karya tulis ini.

Setelah terjadi peristiwa baptisan Roh Kudus pada hari Pentakosta khusus untuk orang-orang Yahudi, selanjutnya kita akan melihat dalam Kisah Para Rasul bahwa baptisan Roh Kudus juga berlaku bagi orangorang Samaria, orang bukan Yahudi (kafir) di rumah Kornelius di Kaisaria, dan akhirnya untuk kedua belas murid Yohanes Pembaptis di Efesus dan mereka semua dipersatukan menjadi satu tubuh Kristus. Setiap peristiwa tersebut terjadi secara terpisah dengan latar belakang yang berbeda dan dengan cara yang bervariasi menurut kedaulatan Allah sendiri.

${ }^{8}$ C. I. Scofield, The New Scofield Reference Bible (New York: Oxford University Press, 1967), 1160. 


\section{Baptisan Roh Kudus pada Hari Pentakosta untuk Kelompok Orang Yahudi yang Sudah Lama Percaya}

Kelompok ini adalah orang-orang Yahudi yang sudah lama percaya dan menjadi murid Tuhan Yesus. Jumlah mereka kira-kira seratus dua puluh orang banyaknya (Kisah 1:15). Kebanyakan dari mereka sempat menyaksikan peristiwa bersejarah tentang kematian, kebangkitan dan kenaikan Tuhan Yesus ke surga, baik secara langsung maupun melalui kesaksian para rasul. Mereka adalah orang-orang yang menerima anugerah keselamatan oleh kematian dan kebangkitan Kristus melalui iman. Pada saat percaya, mereka tidak langsung menerima baptisan Roh Kudus karena Roh Kudus yang dijanjikan itu belum dicurahkan, sebab hari Pentakosta belum tiba. Untuk menerima baptisan Roh Kudus, mereka harus menunggu sampai hari Pentakosta itu tiba. Hal ini terjadi semata-mata disebabkan oleh faktor historis saja.

Menjelang kenaikan Yesus ke surga, Yesus melarang murid-muridNya meninggalkan Kota Yerusalem dan Ia memerintahkan agar mereka tinggal di situ untuk menantikan janji Bapa, yang demikian kata-Nya, "Telah kamu dengar dari pada-Ku. Sebab Yohanes membaptis dengan air, tetapi tidak lama lagi kamu akan dibaptis dengan Roh Kudus" (Kisah 1:4-5). Setelah Yesus naik ke surga, murid-murid-Nya kembali ke kota Yerusalem untuk menunggu kedatangan Roh Kudus di suatu tempat khusus, di ruang atas, tempat mereka menumpang. Di sana mereka semua bertekun dengan sehati berdoa bersama (Kisah 1:12-14). Sekali lagi, hal ini mereka lakukan karena faktor historis. Setelah genap sepuluh hari mereka menunggu, maka janji tentang baptisan Roh Kudus akhirnya terpenuhi. Dengan turunnya Roh Kudus pada hari Pentakosta, kelompok yang berjumlah kira-kira seratus dua puluh orang Yahudi yang sudah lama percaya itu, akhirnya dibaptis dalam Roh Kudus dan pada waktu yang sama mereka pun telah dipenuhi dengan Roh Kudus (Kisah 2:1-4).

Kedatangan Roh Kudus pada hari Pentakosta terjadi secara istimewa yang disertai dengan tanda-tanda khusus seperti suatu bunyi bagaikan tiupan angin keras, lidah-lidah seperti nyala api yang bertebaran, demikian pula orang-orang percaya yang menerima baptisan Roh Kudus itu berkata-kata dalam bahasa lain (bahasa Yunani, heterai glossai, Kisah 2:2-11). Dalam Kisah 2:6 dan 8 digunakan kata "bahasa sendiri", (bahasa Yunani, idia dialekto) yang berarti bahasa ibu dan bahasa suku yang dikenal dan dimengerti serta tidak perlu penerjemah. ${ }^{9}$ Karena faktor historis seperti yang telah dijelaskan di atas, pengalaman yang keseratus dua puluh orang Yahudi yang telah lama percaya itu, setelah

\footnotetext{
${ }^{9}$ Spiros Zodhiates, The Hebrew-Greek Key Study Bible (Grand Rapids, Michigan: Baker Book House, 1985), 1319.
} 
menunggu selama sepuluh hari baru mereka menerima baptisan Roh Kudus pada hari Pentakosta, tidak dapat dijadikan pola untuk kita yang hidup di zaman setelah peristiwa Pentakosta. Coba perhatikan kasus berikut ini, yang berbeda sama sekali.

\section{Baptisan Roh Kudus pada Hari Pentakosta untuk Kelompok Orang Yahudi yang Baru Percaya}

Dalam Kisah 2:14-40, pada hari yang sama, yaitu hari Pentakosta, Rasul Petrus berdiri dengan kesebelas rasul itu berkotbah kepada kelompok orang Yahudi lain yang belum bertobat dan percaya kepada Tuhan Yesus. Adapun isi kotbah Petrus adalah sebagai berikut:

Pertama, kegenapan nubuatan tentang pencurahan Roh Kudus berdasarkan kitab Nabi Yoel (Kisah 2:17-21). Kedua, berita tentang kematian, kebangkitan, dan kenaikan Tuhan Yesus ke surga, serta penggenapan janji pencurahan Roh Kudus berdasarkan nubuatan dalam Perjanjian Lama (Kisah 2:22-36). Ketiga, penutup: tantangan untuk bertobat dan menerima keselamatan (Kisah 2:38-40).

Sebagai respons terhadap kotbah Petrus itu, tiga ribu orang Yahudi mengambil keputusan dan memberi diri dibaptis sebagai tanda pertobatan dan mereka langsung menerima baptisan Roh Kudus serta dipersatukan dengan tubuh Kristus yang keseratus dua puluh orang Yahudi dari kelompok pertama (Kisah 2:41). Walaupun dalam ayat ini tidak disebutkan dengan jelas bahwa ketiga ribu orang Yahudi yang baru bertobat itu telah menerima baptisan Roh Kudus, tetapi berdasarkan Kisah 2:38 dapat disimpulkan bahwa mereka telah menerima "karunia atau baptisan Roh Kudus" pada saat mereka bertobat dan dibaptis dalam nama Tuhan Yesus untuk pengampunan dosa. Peristiwa baptisan Roh Kudus untuk kelompok kedua dari orang Yahudi yang berjumlah tiga ribu orang ini sangat berbeda dengan kelompok pertama dari orang Yahudi yang berjumlah seratus dua puluh orang tadi. Perbedaan antara kedua kelompok ini sangat penting. Mengapa hal itu sangat penting? John R. W. Stott memberi alasan sebagai berikut. "Sebab yang menjadi ukuran untuk masa kini tentu adalah kelompok kedua, bukan kelompok pertama. Kenyataan bahwa pengalaman keseratus dua puluh orang itu terjadi dalam dua tingkat yang berbeda disebabkan oleh keadaan historis. Mereka tidak dapat menerima karunia Pentakosta sebelum hari raya itu terjadi. Itulah sebabnya sekalipun mereka telah dilahirkan kembali, namun belum menerima karunia Roh Kudus. Tetapi, keadaan historis seperti yang dialami keseratus dua puluh orang ini telah lama berhenti. Kini kita hidup di zaman setelah kejadian Pentakosta, seperti halnya ketiga ribu orang itu. Oleh karena itu, kepada kita seperti halnya 
dengan mereka, pengampunan dosa dan baptisan Roh diterima bersamasama." $" 10$

Kelompok orang Yahudi yang berjumlah tiga ribu orang ini pada mulanya tidak percaya, tetapi ketika mereka bertobat dan menerima pengampunan dosa, pada saat itu juga mereka langsung menerima baptisan Roh Kudus, tanpa menunggu seperti yang dilakukan oleh keseratus dua puluh orang Yahudi dari kelompok pertama. Tidak pula kita jumpai bahwa yang ketigaribu orang itu berkata-kata dalam bahasabahasa lain sebagai akibat dari baptisan Roh Kudus seperti yang dialami oleh kelompok pertama, Yang merupakan ayat kunci mengenai baptisan Roh Kudus untuk yang ketiga ribu orang ini adalah dalam Kisah 2:38. Dalam ayat ini ada dua kata kerja perintah, yaitu "Bertobatlah", (Metanoesate, aorist imperative) dan "dibaptislah", (baptistheto, aorist passive imperative), sedangkan kata kerja "akan menerima" (lempsesthe, adalah dalam bentuk future middle indicatif). Lengkapnya anak kalimat itu adalah "maka kamu akan menerima karunia Roh Kudus", (lempsesthe ten dorean tou hagiou pneumatos).

Dari analisis ini dapat disimpulkan bahwa hal menerima baptisan Roh Kudus bukan sesuatu yang diperintahkan, melainkan merupakan akibat dari perintah "Bertobatlah dan dibaptislah" untuk pengampunan dosamu. Baptisan Roh Kudus untuk yang ketiga ribu orang Yahudi dari kelompok kedua ini tidak perlu lagi disertai dengan tanda-tanda yang istimewa atau berkata-kata dalam bahasa-bahasa lain, seperti yang dialami oleh keseratus dua puluh orang Yahudi dari kelompok pertama. Alasannya ialah karena baptisan Roh Kudus yang terjadi untuk ketiga ribu orang Yahudi ini adalah "suatu kejadian yang normal", yang berlaku umum dari peristiwa bersejarah yang terjadi pada hari Pentakosta, satu kali untuk selama-lamanya, dengan mengikutsertakan semua orang percaya, yang terjadi pada saat orang bertobat (termasuk yang ketiga ribu orang Yahudi ini) ke dalam tubuh Kristus (dipersatukan menjadi tubuh Kristus).

Sehubungan dengan itu, John R. W. Stott menulis sebagai berikut, "Pentakosta adalah kejadian terakhir dari riwayat pekerjaan Yesus Kristus, yaitu pencurahan Roh Kudus yang telah lama dinanti-nantikan sebagai buah dari kematian, kebangkitan, dan kenaikan-Nya ke surga. Dengan demikian, Pentakosta melengkapi awal zaman baru dan zaman Mesias, zaman Roh. Pada diri-Nya kejadian itu tak dapat diulangi seperti halnya dengan kematian, kebangkitan, dan kenaikan-Nya ke surga yang mendahuluinya, tak dapat diulang. Tetapi, berkatnya diperuntukkan

${ }^{10}$ John R.W. Stott, Baptisan dan Kepenuhan (Jakarta: BPK Gunung Mulia, n.d.), 12- 
bagi semua orang yang menjadi milik Kristus. Dalam arti ini, mereka yang bertobat pada hari Pentakosta sebagai hasil kotbah Petrus menjadi pola bagi semua orang percaya berikutnya. ${ }^{11}$

Bagi para rasul, peristiwa penyaliban, kebangkitan, dan kenaikan Yesus ke surga, serta baptisan Roh Kudus harus dilalui selama tiga tahun, tetapi bagi kita yang hidup dua ribu tahun sesudah hari Pentakosta, manfaat kematian, kebangkitan, kenaikan Yesus ke surga, serta baptisan Roh Kudus hanya terjadi pada waktu yang sangat singkat, yaitu pada saat kita bertobat dan menerima Yesus sebagai Juruselamat, sama seperti yang dialami oleh ketiga ribu orang Yahudi yang bertobat pada hari Pentakosta sebagai hasil kotbah Petrus.

\section{Baptisan Roh Kudus Sesudah Hari Pentakosta untuk Kelompok Orang Samaria yang Percaya}

Di atas telah diuraikan bahwa kelompok orang Yahudi yang baru percaya pada hari Pentakosta, langsung menerima baptisan Roh Kudus pada saat bertobat, tanpa menunggu lagi. Sekarang kita akan melihat kasus yang terjadi pada kelompok orang Samaria yang percaya sesudah hari Pentakosta dalam Kisah 8:4-25.

Ketika terjadi penganiayaan yang hebat terhadap jemaat di Yerusalem, semua orang Kristen tersebar ke seluruh daerah Yudea dan Samaria (Kisah 8:1). Filipus, salah seorang yang dipilih menjadi pelayan jemaat (Kisah 6:5) pergi memberitakan Injil disuatu kota di Samaria dengan disertai tanda-tanda dan mukjizat. Akibat dari pemberitaan Injil Filipus, banyak orang Samaria percaya kepada Tuhan Yesus dan memberi diri dibaptis, baik laki-laki maupun perempuan (Kisah 8:16). Selanjutnya Lukas melaporkan bahwa ketika rasul-rasul di Yerusalem mendengar bahwa tanah Samaria telah menerima firman Allah, mereka mengutus Rasul Petrus dan Yohanes untuk mendoakan orang-orang Samaria yang sudah percaya dan dibaptis itu supaya mereka menerima baptisan Roh Kudus. Setelah kedua rasul itu menumpangkan tangan ke atas mereka, barulah mereka menerima baptisan Roh Kudus (Kisah 8:1417). Peristiwa yang terjadi pada kelompok orang Samaria ini berbeda dengan pengalaman kelompok orang Yahudi yang sudah percaya sebelum hari Pentakosta. Kelompok orang Yahudi itu telah menerima baptisan Roh Kudus tanpa penumpangan tangan para rasul, sedangkan kelompok orang Samaria baru menerima baptisan Roh Kudus dengan penumpangan tangan oleh dua orang rasul. Di sini terjadi hal yang tidak biasa, sesuatu yang menyimpang. Mengapa demikian? Kembali jawabannya karena faktor historis.

${ }^{11}$ Ibid., 13. 
Menurut latar belakang sejarah, orang Samaria adalah keturunan orang Yahudi dan orang Asyur. Mereka tetap menyembah dewa-dewa mereka, tetapi juga menyembah Tuhan bersama-sama dengan berhala mereka. Sesudah orang Yahudi bebas dari tawanan di Negeri Babel, mereka ingin menolong untuk membangun kembali Bait Allah di Yerusalem, tetapi Nehemia menolak pertolongan mereka. Karena itu, mereka melawan orang-orang Yahudi. Lalu orang Samaria mendirikan Kaabah sendiri di Gunung Gerizim. Imam mereka yang pertama ialah Manasye yang menikah dengan perempuan Persia. Agama mereka setengah kafir dan setengah Yahudi. Karena itu, bangsa Yahudi lebih membenci mereka daripada membenci bangsa lain yang benar-benar kafir. $^{12}$

Tetapi sekarang, bukan hanya orang Yahudi berkotbah kepada orang Samaria, melainkan orang-orang Samaria yang merupakan musuh turun-temurun bagi bangsa Yahudi itu justru telah menerima pemberitaan dari orang Yahudi. Timbul pertanyaan dari rasul-rasul di Yerusalem, apakah kiranya mereka dapat diterima oleh orang-orang percaya dari bangsa Yahudi? Atau apakah permusuhan dan perpecahan kuno antara orang Yahudi-Samaria akan hidup kembali di dalam gereja dan menjadi satu bencana perpisahan antara orang Kristen Yahudi dan orang Kristen Samaria? Inilah yang merupakan kunci mengapa Roh Kudus tertunda memasuki orang-orang Samaria sampai kedatangan Rasul Petrus dan Yohanes supaya mereka sendiri melihat bahwa Allah menerima orang-orang Samaria yang dibenci itu, karena mereka percaya kepada Kristus. Petrus dan Yohanes tidak usah ragu-ragu lagi. ${ }^{13}$

Dengan baptisan Roh Kudus ke atas orang-orang Samaria yang disaksikan oleh rasul-rasul Yahudi, Allah mau menyatakan bahwa Ia tidak menghendaki terjadi perpecahan dan perpisahan antara orang Kristen Yahudi dan orang Kristen Samaria. Sebaliknya, melalui baptisan Roh Kudus, Allah mau mempersatukan keduanya menjadi satu tubuh Kristus, tanpa perbedaan (Efesus 2:13-20). Perlu diperhatikan bahwa orang-orang Samaria tidak berbahasa roh sebagai akibat baptisan Roh Kudus.

Karena faktor historislah, maka kejadian di Samaria memiliki kekhususan, sehingga Roh Kudus tertunda diberikan kepada orangorang Samaria yang telah percaya sampai rasul-rasul Yahudi datang dan menumpangkan tangan ke atas mereka. Oleh sebab itu, kejadian yang khusus yang telah terjadi terhadap orang-orang Samaria dalam hal

${ }^{12} \mathrm{~J}$. Wesley Brill, Tafsiran Injil Yohanes (Bandung: Penerbit Kalam Hidup, n.d.), 49-

${ }^{13}$ Billy Graham, Roh Kudus (Bandung: Lembaga Literatur Baptis, 1978), 100. 
menerima baptisan Roh Kudus tidak dapat dijadikan sebagai pola bagi kita yang hidup pada masa kini.

\section{Baptisan Roh Kudus Sesudah Hari Pentakosta untuk Kelompok Orang Bukan Yahudi di Kaisaria}

Dalam Kisah 10 dan 1l, tibalah saatnya Allah mengunjungi keluarga Kornelius dan orang-orang bukan Yahudi lainnya di Kaisaria. Melalui suatu penglihatan yang aneh, Rasul Petrus sebagai orang Yahudi diperintahkan oleh Allah untuk memberitakan kabar kesukaan kepada kelompok orang bukan Yahudi di Kaisaria itu. Petrus sebagai seorang Yahudi tulen yang masih tetap berpegang pada sifat keyahudiannya yang sangat ketat di mana orang-orang Yahudi dilarang keras bergaul dengan orang-orang bukan Yahudi karena mereka dianggap najis. Melalui penglihatan itu seolah-olah Allah memaksa Petrus untuk pergi kepada orang-orang bukan Yahudi, karena Allah mau memanggil orang-orang bukan Yahudi juga untuk dipersatukan dengan orang-orang Yahudi menjadi satu tubuh Kristus melalui baptisan Roh Kudus, sehingga tidak ada lagi perbedaan antara orang Kristen Yahudi dan orang Kristen bukan Yahudi (Kisah 15:7-9). Ketika Rasul Petrus memberitakan Injil tentang pengampunan dosa, maka turunlah Roh Kudus ke atas semua orang yang mendengar pemberitaan itu (Kisah 10:44). Melihat peristiwa itu, semua orang Yahudi yang menyertai Petrus tercengang-cengang sebab mereka mendengar dan menyaksikan langsung bahwa orang-orang itu berkatakata dalam bahasa roh dan memuliakan Allah. Kemudian mereka dibaptis dengan air dalam nama Yesus Kristus (Kisah 10:45-48). Pada peristiwa di tempat lain, baptisan Roh Kudus mengikuti baptisan air. Tetapi terhadap orang-orang bukan Yahudi terjadi sebaliknya, yaitu baptisan Roh Kudus mendahului baptisan air.

Dalam peristiwa yang terjadi di dalam rumah Kornelius merupakan pengulangan tanda ajaib Pentakosta dengan maksud supaya orang-orang Yahudi yang sangat fanatik itu dapat mengakui dan mengetahui bahwa Allah sebenarnya tidak membedakan lagi antara orang-orang Yahudi dengan orang-orang bukan Yahudi. Dengan perantaraan salib Kristus, dinding pemisah yang ada di tengah itu telah dirobohkan oleh Yesus Kristus. Dan baptisan Roh Kudus yang diterima oleh bangsa Yahudi boleh juga diterima oleh orang-orang bukan Yahudi dengan cara yang sama. Bahasa roh yang diberikan kepada mereka dengan maksud untuk memperkuat kebenaran tersebut. ${ }^{14}$

Hal penting yang perlu diperhatikan dari peristiwa baptisan Roh Kudus untuk orang-orang bukan Yahudi di sini ialah bahwa baptisan

${ }^{14}$ Tjhung Tek Kie, Parakletos (Surabaya: Penerbit the Chinese Foreign Missionary Union Book Room, n.d.), 73-74. 
Roh Kudus merupakan peristiwa permulaan dalam kehidupan orang percaya yang terjadi pada saat orang percaya kepada Kristus untuk dimasukkan ke dalam tubuh Kristus (Kisah 1l:17).

\section{Baptisan Roh Kudus Sesudah Hari Pentakosta untuk Kelompok Murid Yohanes Pembaptis di Efesus}

Ketika Rasul Paulus mengadakan perjalanan yang ketiga dalam pekabaran Injil, ia tiba di Efesus. Di situ ia bertemu dengan sekelompok murid yang jumlahnya kira-kira dua belas orang (Kisah 19:1, 7). Rupanya yang dimaksud dengan istilah "murid" di sini bukan murid Yesus, melainkan murid Yohanes Pembaptis, karena ketika Paulus menanyakan tentang baptisan, mereka hanya mengetahui baptisan Yohanes Pembaptis. Tampaknya Paulus curiga terhadap kehidupan kekristenan mereka. Itu nyata dari pertanyaan yang dilontarkan oleh Paulus kepada mereka, "Sudahkah kamu menerima Roh Kudus ketika kamu percaya?" Mereka menjawab, "Belum, bahkan kami belum pernah mendengar bahwa ada Roh Kudus" (Kisah 19:2). Dari semua jawaban mereka membuktikan bahwa mereka bukan orang Kristen sama sekali karena mereka belum menerima Kristus.

Tampaknya mereka adalah murid Yohanes Pembaptis yang belum mengenal Kristus dan Roh Kudus. Sebab itu, mereka tidak dapat disebut orang Kristen. Setelah mereka mendengar tentang pemberitaan Paulus, barulah mereka menjadi pengikut Kristus yang sesungguhnya. Kemudian mereka memberi diri dibaptis dalam nama Tuhan Yesus. Dan ketika Paulus menumpangkan tangan ke atas mereka, mereka mulai berkatakata dalam bahasa roh dan bernubuat (Kisah 19:5,6).

Menurut John R. W. Stott, ada penafsir-penafsir yang menaruh perhatian pada urutan peristiwa dalam bagian ini, yaitu (1) percaya kepada Yesus; (2) dibaptis dalam nama Yesus; (3) penumpangan tangan oleh Paulus; dan (4) turunnya Roh Kudus. Mereka menekankan bahwa Roh Kudus turun ke atas orang-orang Efesus ini bukan pada saat mereka percaya, melainkan setelah Paulus membaptis dan menumpangkan tangan atas mereka. ${ }^{15}$ Penulis tidak setuju dengan penafsir-penafsir tersebut yang memisahkan peristiwa yang satu dengan yang lain. Semua urutan peristiwa yang terjadi atas kedua belas murid itu merupakan satu kesatuan yang tidak dapat dipisahkan antara kejadian yang satu dengan yang lain. Hal ini sejalan dengan pernyataan John R. W. Stott dalam bukunya yang berjudul Baptisan dan Kepenuhan, "Pokok yang benar-benar penting ialah bahwa empat kejadian itu semuanya menunjukkan suatu kesatuan yang tak dapat dipisah-pisahkan. Keempat kejadian itu adalah

${ }^{15}$ John R. W. Stott, Baptisan dan Kepenuhan (Jakarta: BPK Gunung Mulia, n.d.), 20. 
bagian yang bermacam-macam dari satu upacara penerimaan ke dalam Kristus, yang terjadi dengan baptisan dan penumpangan tangan secara lahiriah dan dengan iman serta karunia Roh secara batiniah." ${ }^{\text {.6 }}$

Sekali lagi peristiwa yang terjadi di Efesus merupakan suatu kejadian yang unik, lain dari biasanya, yang hampir sama dengan apa yang terjadi dengan orang-orang Samaria dalam Kisah 8, tetapi dengan latar belakang yang berbeda. Merill Tenney menyebutkan mereka sebagai "orang-orang percaya yang terlambat". ${ }^{17}$ Mereka telah lama dibaptis dan menjadi murid Yohanes Pembaptis, tetapi belum mengenal Kristus dan Roh Kudus. Itu sebabnya mereka belum menerima baptisan Roh Kudus. Mereka baru benar-benar menjadi Kristen setelah Paulus memberitakan Kristus dan Roh Kudus. Setelah mereka dibaptis dalam nama Tuhan Yesus, mereka pun menerima baptisan Roh Kudus melalui penumpangan tangan. Jadi, jelaskan bahwa baptisan Roh Kudus bukanlah berkat kedua dari Roh Kudus, melainkan peristiwa permulaan yang terjadi pada saat orang percaya untuk dipersatukan ke dalam tubuh Kristus.

\section{Pengertian tentang Baptisan Roh Kudus}

Sebelum penulis memberikan pengertian tentang baptisan Roh Kudus dalam satu definisi, ada dua hal yang perlu diperhatikan kembali sebagai dasar.

Pertama, ringkasan sejarah baptisan dalam Roh Kudus dalam Kisah Para Rasul: 1) Baptisan Roh Kudus pada hari Pentakosta adalah peristiwa bersejarah yang tak pernah diulang, satu kali untuk selamalamanya: a) yang berlaku untuk orang-orang Yahudi yang sudah lama percaya, tetapi karena faktor historis, mereka harus menunggu sampai hari Pentakosta tiba. Peristiwa itu disertai tanda-tanda yang luar biasa dan bahasa-bahasa lain yang dimengerti; b) yang berlaku untuk orangorang Yahudi yang baru percaya pada hari Pentakosta dan mereka tidak perlu menunggu lagi. Peristiwa itu terjadi pada saat mereka bertobat dan tidak lagi disertai tanda-tanda istimewa dan bahasa-bahasa lain. Kedua kelompok orang Yahudi ini dipersatukan menjadi satu tubuh Kristus yang disebut gereja pertama (Kisah pasal 2); 2) Baptisan Roh Kudus berlaku untuk orang-orang Samaria yang merupakan musuh turuntemurun bangsa Yahudi. Karena faktor historis, peristiwa itu harus disahkan oleh dua orang rasul Yahudi melalui penumpangan tangan dan tidak disertai tanda bahasa roh. Kemudian mereka pun diterima dan dipersatukan dengan orang-orang percaya dari bangsa Yahudi menjadi

\footnotetext{
${ }^{16}$ Stott, Baptisan dan Kepenuhan, 20.

${ }^{17}$ Merril Tenney, dalam Billy Graham, Roh Kudus (Bandung: Lembaga Literatur Baptis, 1978), 103.
} 
satu tubuh Kristus tanpa mengenal perbedaan (Kisah 8); 3) Baptisan dalam Roh Kudus juga berlaku untuk orang-orang bukan Yahudi (kafir) yang dipandang hina dan najis oleh bangsa Yahudi. Karena faktor historis, peristiwa ini harus disahkan dan disaksikan oleh seorang rasul Yahudi dan orang-orang Kristen Yahudi yang menyertainya. Peristiwa ini terjadi pada saat mereka percaya dan disertai bahasa roh, tetapi tanpa penumpangan tangan (Kisah 10-11); 4) Baptisan Roh Kudus tidak berlaku bagi orang-orang yang belum menjadi Kristen, tetapi hanya untuk mereka yang percaya sungguh-sungguh kepada Kristus. Contoh, kelompok kedua belas murid Yohanes Pembaptis di Efesus (Kisah 19:17).

Kedua, Penjelasan tentang pengertian dan tujuan baptisan Roh Kudus berdasarkan 1 Korintus 12:13. Satu-satunya ayat dalam surat kiriman yang berhubungan langsung dengan baptisan Roh Kudus yang bersifat doktrinal adalah 1 Korintus 12:3. Untuk itu, penulis mengutip ayat ini selengkapnya: "Sebab dalam satu Roh kita semua, baik orang Yahudi maupun orang Yunani, baik budak maupun orang merdeka, telah dibaptis menjadi satu tubuh dan kita semua diberi minum dari satu Roh." Supaya lebih jelas, ayat ini disusun sebagai berikut, "Sebab kita semua, baik orang Yahudi maupun orang Yunani, baik budak maupun orang merdeka, telah dibaptis dalam satu Roh, menjadi satu tubuh dan kita semua telah diberi minum dalam satu Roh." Inilah satu-satunya ayat yang memberi keterangan yang jelas pada pengertian dan tujuan dari pelayanan Roh Kudus. Satu akibat penting dari baptisan Roh Kudus ialah bahwa orang-orang percaya dipersatukan ke dalam tubuh Kristus, yaitu gereja. Dari teks ini muncul empat fakta: ${ }^{18} 1$ ) Baptisan Roh Kudus adalah untuk "semua orang percaya" dan bukan pengalaman dari beberapa orang pilihan saja, "Kita semua telah dibaptis"; 2) Baptisan Roh Kudus adalah suatu peristiwa yang telah lampau dalam kehidupan orang percaya. Bentuk waktu aorist menunjukkan ini, "kita semua telah"; 3) Baptisan Roh Kudus berhubungan dengan orang-orang percaya yang dimasukkan atau digabung ke dalam tubuh Kristus oleh persatuan yang hidup dan organik yang diakibatkan oleh Roh Kudus. Melalui persatuan itu ia ada "di dalam Kristus" dengan semua berkat yang diakibatkannya; 4) Tidak ada perbedaan di antara orang-orang percaya dalam hal ini. Baptisan dalam Roh menjamin kesatuan anggota-anggota yang merupakan tubuh Kristus. "Dalam satu Roh kita semua telah dibaptis menjadi satu tubuh, baik orang Yahudi maupun orang Yunani, baik budak maupun orang merdeka, dalam baptisan kita semua telah diberi minum dalam satu Roh."

\footnotetext{
${ }^{18}$ Sanders, J. Oswald The Holy Spirit and His Gifts (Grand Rapids, Michigan: Zondervan Publishing House, 1970.
} 


\section{PENUTUP}

\section{Kesimpulan}

Dari semua uraian di atas dapat disimpulkan dalam satu definisi tentang baptisan Roh Kudus secara alkitabiah sebagai berikut. Baptisan Roh Kudus bukan suatu pengalaman yang harus dicari dan diusahakan dan bukan pula merupakan berkat kedua sesudah pertobatan. Baptisan Roh Kudus adalah suatu peristiwa bersejarah masa lampau yang dilakukan oleh Yesus Kristus pada hari Pentakosta, yang tidak pernah diulang, satu kali untuk selama-lamanya, dengan mengikutsertakan semua orang percaya, yang terjadi pada saat orang percaya dan menerima Yesus Kristus sebagai Tuhan dan Juruselamat, dengan tujuan untuk mempersatukan semua orang percaya dalam persatuan yang hidup dan organik, baik orang Yahudi maupun orang Yunani, baik budak maupun orang merdeka menjadi satu tubuh Kristus, yaitu gereja. 


\section{KEPUSTAKAAN}

Alkitab. Jakarta: Lembaga Alkitab Indonesia, 2012.

Aland, Kurt, cs. The Greek New Testament. Federal Republic of Germany: The United Bible Societies, 1983.

Scofield, I. C. The New Scofield Reference Bible. New York: Oxford University Press, 1967.

Zodhiates, Spiros. The Hebrew-Greek Key Study Bible. Grand Rapids, Michigan: Baker Book House, 1985.

Brill, J. Wesley. Tafsiran Injil Yohanes. Bandung: Penerbit Kalam Hidup, n.d.

Graham, Billy. Roh Kudus. Bandung: Lembaga Literatur Baptis, 1978.

Kie, Tjhung Tek. Parakletos. Surabaya: The Chinese Foreign Missionary Union Book Room, n.d.

Newman, Barclay M. dan Eugene A. Nida. Pedoman Tafsiran Alkitab. Jakarta: Lembaga Alkitab Indonesia, 2008.

Park, Yune Sun. Tafsiran Alkitab Kisah Para Rasul. Batu: Departemen Literatur YPPII, 2001.

Sanders, J. Oswald. The Holy Spirit and His Gifts. Grand Rapids, Michigan: Zondervan Publishing House, 1970.

Roh Kudus Penolong Kita. Jakarta: BPK Gunung Mulia untuk OMF, 1985.

Tong, Stephen. Baptisan dan Karunia Roh Kudus. Surabaya: Momentum, 2011.

Stott, John W.R. Baptisan dan Kepenuhan. Jakarta: BPK Gunung Mulia, 1974.

Sugiri, L. Gerakan Kharismatik. Apakah Itu? Jakarta: BPK Gunung Mulia, 1985.

Sutanto, Hasan. Perjanjian Baru Interlinear: Yunani-Indonesia dan Konkordasi Perjanjian Baru (PBIK) Jilid I dan II. Jakarta: Lembaga Alkitab Indonesia, 2003. 